
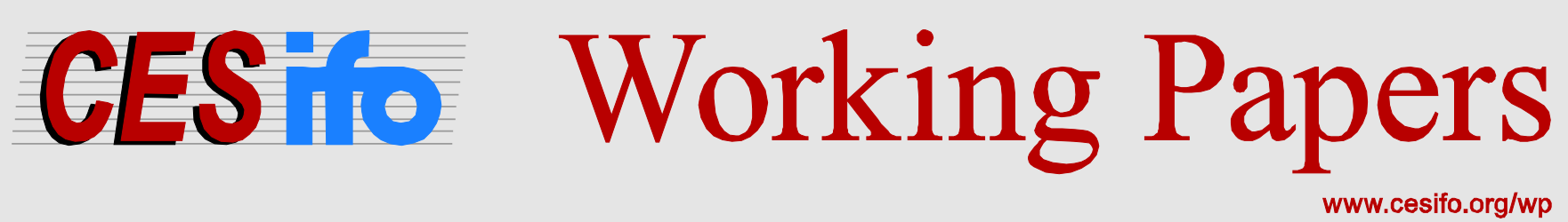

\title{
Demographic Transition and Political Stability: Does Corruption Matter?
}

\author{
Mohammad Reza Farzanegan \\ Stefan Witthuhn
}

CESIFO WORKING PAPER NO. 5133

CATEgOry 2: Public CHOICE

DECEMBER 2014

\footnotetext{
An electronic version of the paper may be downloaded

- from the SSRN website:

- from the RePEc website:

- from the CESifo website:

wWw.SSRN.com

Www.RePEc.org

www.CESifo-group.org/wp
}

\section{CESifo}




\title{
Demographic Transition and Political Stability: Does Corruption Matter?
}

\begin{abstract}
A demographic transition resulting from an increase in the size of the young working age population can be a blessing or a curse for economic performance. We focus on the political stability effects of a larger youth population and hypothesize that corruption matters in this nexus. Using panel data covering the period of 2002-2012 for more than 150 countries, we find a negative interaction effect between the relative size of the youth population (17-25 years old) within the total working age population (15-64 years old) and corruption on political stability. This finding is robust, controlling for country and time fixed effects and a set of control variables that may affect stability. The negative interaction term between corruption and the youth population remains robust when we control for the persistency of political stability and the possible endogeneity of the main variables of interest through dynamic panel data estimations. Our findings shed more light on the political turmoil in the Arab world, with the so-called Arab Spring.
\end{abstract}

JEL-Code: D730, D740, E020, H560, J110.

Keywords: demographic transition, youth population, political stability, corruption.

Mohammad Reza Farzanegan*

CNMS, Middle East Economics

Department / University of Marburg

Deutschhausstrasse 12

Germany-35032 Marburg

farzanegan@uni-marburg.de
Stefan Witthuhn

Center for Near and Middle Eastern

Studies (CNMS) / University of Marburg

Deutschhausstrasse 12

Germany - 35032 Marburg

witthuhn@students.uni-marburg.de

*corresponding author

This version: 12.1.2015

We would like to thank the useful comments of Pooya Alaedini, Sajjad Dizaji, and Alireza Naghavi. 


\section{1- Introduction}

Our study focuses on the analysis of two factors that affect political stability, namely demographic transitions and corruption. Demographic transitions take different shapes, but the proxy highlighted in a political stability context is the 'youth bulge', a large percentage of young people in society. The likely negative impact of a large youth cohort on political stability has been highlighted theoretically (Moller 1968; Huntington 2002; Goldstone 2002) and empirically (Weber 2013; Urdal 2006; Barakat and Urdal 2009; Bricker and Foley 2013). Youth bulges appear to increase the risk of conflict through several channels (Goldstone 2002). The fact that several countries in the Middle East have large youth bulges, with approx. $30 \%$ of their working age populations in the youth age group, appears to be a powerful explanatory factor for recent uprisings in the region. The identification of key variables that mediate the stability effects of demographic transitions is urgently needed in light of the present and upcoming demographic challenges facing the world. In particular, developing countries with high birth rates, like Nigeria, Yemen and Somalia, raise concerns in this context.

These youths face limited opportunities. We suggest that a large youth cohort alone is not a sufficient driver for political instability but that it is conditional on social, economic and political factors, as shown by Bricker and Foley (2013) and Barakat and Urdal (2009). The factor under investigation in our analysis is corruption, suggesting that the chance of political instability increases in countries with a large youth cohort in the presence of pervasive corruption. One of the frequently suggested triggers for the so-called Arab Spring is corruption (Nur-Tegin and Czap 2012). Egypt ranked 70/158 in the 2005 Corruption Perception Index (CPI) by Transparency International ${ }^{1}$ and deteriorated to $115 / 180$ in 2008 ${ }^{2}$ (Diwan 2013). Syria shifted from $70 / 158$ to $147 / 180$ in the same period (Transparency International 2008). Corruption appears to have increased in these countries, and corruption might have instability effects not only because of its negative economic consequences but also due to the diminishing opportunities for people to fully participate in social, economic and political life in corrupt systems. Pressures on the labor market and the environment are already high during demographic transitions, and corruption might amplify instability effects. A recent study by Onuoha (2014) highlights the role of widespread corruption in Nigeria as

\footnotetext{
${ }^{1}$ http://www.transparency.org/research/cpi/cpi_2005/0/

2 http://www.transparency.org/research/cpi/cpi_2008/0/
} 
one of the drivers of expansion of the "Boko Haram"3 group and the increasing youth memberships in it. The economic costs of corruption increase when the costs of political instability enter the calculation. ${ }^{4}$

This paper adds to the literature in three ways. The main contribution is an empirical test of the relevance of corruption as an intermediary channel in a youth bulge - political stability nexus. Several studies highlight the importance of corruption and demographic transitions as triggers of political instability, but empirical tests of an interaction have yet to be completed. The present paper fills this gap and analyzes the joint effects on political stability. We show that the final stability effects of demographic change depend on the level of corruption. The second contribution is the use of a large sample and the latest data. Several countries affected by the so-called Arab Spring witnessed increased perceived corruption prior to the uprisings. These developments are covered by the time period of our dataset. The third contribution is the operationalization of (one- and two-step) system Generalized Methods of Moments to control for the persistence of dependent variables and the endogeneity of some regressors.

The remainder of this paper is structured as follows. Section 2 presents and discusses the literature on the determinants of political stability and the roles of demography and corruption in stability. Section 3 explains the data, the empirical methodology, the main results and robustness analyses. Section 4 concludes the paper.

\section{2- Review of theoretical and empirical literature}

This section examines the main variables under investigation in this paper, beginning with political stability as the dependent variable, followed by the key variables, demographic transitions and corruption.

\subsection{Political stability}

The existing literature offers a range of determinant factors for (in)-stability. Inequality in income distribution is identified as a driver of instability (Alesina and Perotti 1996) and also GDP growth (Alesina et al. 1996) is linked to stability. Alesina et al. (1996) find more evidence that causality goes from political stability to GDP growth than vice versa.

Institutional quality has been highlighted as an explanatory variable for political stability in a number of studies. A portion of the literature applies measures for formal institutions that capture the existence of (political) institutions rather than outcomes. The results suggest an inverted U-shape nexus between institutional quality and political stability. Fully autocratic

\footnotetext{
${ }^{3}$ Boko Haram is an extremist sect in Nigeria that has a radical interpretation of Islam and combats modern symbols, such as education, especially with respect to women. Their terrorist activities have caused significant damage in Northern Nigeria, undermining the stability of this oil-rich country.

${ }^{4}$ See Dreher and Herzfeld (2005) for the economic costs of corruption and Salti (2013) for the economic costs of political instability in Lebanon
} 
and fully democratic regimes appear to be most stable, whereas countries with intermediate levels of institutional quality are more prone to instability (Urdal 2006, Barakat and Urdal 2009, Schomaker and Wentzel 2014). Niang (2010) finds that rather than regime type, the durability of a regime lowers the chance of violence. Bricker and Foley (2013) apply a measure for rule of law. The results support the expectation that higher institutional quality decreases the risk of conflict.

Recent studies that have been undertaken to investigate the stability effects of demographic transitions focus on the argumentation that young men pose threats to political stability via intolerance and extremist political ideas (Weber 2013) or try to capture moderating factors that can explain political stability in the youth bulge context. The moderating factors under investigation are mostly economic ones, such as unemployment and pressure on the labor market in transitional periods with high dependency ratios (Urdal 2006; Bricker and Foley 2013). Other factors are rarely found in empirical works, with the exception of institutional quality and education (Barakat and Urdal 2009), but qualitative works clearly suggest digging deeper for social and political factors to understand recent revolts in the Middle East and worldwide (Yousef 2003; Diwan 2013).

\subsection{Demographic Transition}

The term demographic transition is used to describe observable changes in birth and mortality rates and the corresponding population growth. Demographic transitions go through several stages. The first stage is characterized by high birth rates and high mortality rates. Birth rates exceed mortality rates during the second stage, resulting in high population growth. The third stage witnesses low birth rates and low mortality rates (Doces 2011). The first and third stages represent low population growth, but this work is interested in learning about the effects of the second stage. High population growth over a limited period of time consequently leads to a relative large youth cohort. A relatively large working age population is also called a 'window of opportunity' because one can assume that a country can prosper when there are relatively many people working, supporting a relatively small non-working age population (Chaaban 2009).

While some countries can take advantage of this opportunity, a large working age population can also be a challenge if the state's capability to deal with the situation is limited. The competition for finite resources increases and socio-economic demands (like housing, education and job opportunities) have to be met (Nordås and Davenport 2013). The job market is under pressure due to the high demand for job opportunities, and the young adult generation is likely to be the most unsatisfied because youth unemployment is generally 
higher than total unemployment (Barakat and Urdal 2009). If a large youth cohort coincides with a stagnant economy and vast unemployment, the chances for political instability rise also because of the low opportunity costs for young men to engage in political violence (Weber 2013; Bricker and Foley 2013; Yousef 2003). Definitions for youth bulges can be found in a variety of studies, and the age structure and gender-related data often differ. A conventional youth bulge proxy is the 15-24-year-old male population as a share of all males aged 15 and older (Urdal 2006). Another possible age-set is the male population aged 15-29 divided by the total male population aged 15 and older (Weber 2013). A new approach is presented by Bricker and Foley (2013), who convincingly argue that the age-set 17-26 is more interesting to look at in a socio-economic research. They suggest that this group of young adults is looking for full-time employment and chances are high that they will engage in political violence if unsatisfied. Their Youth Risk Factor is defined as the share of 17-26 divided by the size of the total labor force.

\subsection{Corruption}

Corruption, defined here as the misuse of public office for private gain (Treisman 2000), is the most complex variable under investigation. Causes of corruption can also be consequences. In our analysis, corruption may affect political stability, but political stability itself reduces corruption (Treisman 2000; Nur-Tegin and Czap 2012). While the positive correlation between corruption and political instability is striking (Schumacher 2013), the study of its causes and consequences is somewhat complex (Lambsdorff 2007). Despite this burden, a growing number of studies on corruption present useful results for our analysis. The following is an overview of effects that are identified to be consequences of corruption and how these are linked to demographic transitions and political stability. Lambsdorff (2007) highlights the importance of corruption's effects on inequality. The impact of corruption on income inequality is statistically significant, as shown by Gupta et al. (2002) in a cross section of 37 countries by using Ordinary Least Squares (OLS) and instrumental variable techniques to address endogeneity problems. Following this causality, a relevant finding is presented by Alesina and Perotti (1996) from a sample of 71 countries and a dataset covering 1960-85. Estimating a system of two equations to take into account endogeneity, the findings show that income inequality increases socio-political instability.

Corruption distorts public funds towards areas where bribes can be more easily collected, such as capital intensive infrastructure projects, rather than investing in the employmentintensive health care and education sectors (Mauro 1995; Gupta, Davoodi, and Tiongson 2001; Blackburn and Sarmah 2008). Peoples' talents concentrate on rent seeking in corrupt 
societies, rather than focusing on long-term benefits (Mo 2001). Corruption affects the poor by reducing social services. In contrast, it can be argued that it benefits the well-connected individuals of society, who are likely to be found in the high-income class (Gupta, Davoodi, and Alonso-Terme 2002). Finally, corruption itself can motivate people to participate in public protests or can cause instability at the hands of corrupt regime officials (Treisman 2000).

A further study (Mo, 2001) links corruption to political stability by investigating the transmission channels of corruption on economic growth. The results show that a one-unit increase in corruption in the 1999 Transparency International-CPI corruption index reduces economic growth by 0.545 percentage points. One of the major transmission channels of .growth effects of corruption is political stability. Political instability following increasing corruption accounts for 53\% of total negative effect of corruption on growth. Other channels through which corruption reduces growth are negative effects on human capital and private investment. This result indicates causality between corruption and political stability while focusing on the negative outcome for economic development. An earlier study suggests that the impact of corruption on economic growth is largely via its impact on the investment ratio to GDP (Mauro 1995).

Whereas the abovementioned studies identify consequences of corruption, another part of the literature analyzes its determinants. This literature demonstrates the influence of political regimes on corruption and provides evidence that corruption is lower in democratic countries (Nur-Tegin and Czap 2012) and that democratic election processes decrease corruption (Schumacher 2013; Treisman 2000). In contrast, newly founded democracies might not reduce corruption or provide economic and political stability (Nur-Tegin and Czap 2012). Rather, improvements in control of corruption can be found in decade-long democracies (Treisman 2000). It also seems to be important to distinguish between the natures of corruption. If a briber can be sure that he gets what he wants in return for his bribes, the effect on investments might be less severe in comparison to bribes where the briber remains unsure (Mauro 1995; Lambsdorff 2007).

As shown above, several findings suggest a link between corruption and political (in)stability. Corruption affects a series of measures that can ease or challenge the pressure of a large youth cohort in a political stability context. Corruption not only has direct economic effects on growth and investment, for example, but also affects the political behavior of individuals. On the basis of the related literature, we present the following hypothesis, which will be evaluated empirically: 
Hypothesis: The final effect of a demographic transition (youth bulge) on political stability depends on the level of corruption. An increasing youth bulge will be a challenge for the stability of political systems with high corruption, ceteris paribus.

\section{3- Empirical research design}

\subsection{Data, specification, and empirical strategy}

Our main hypothesis is that increasing the relative size of youth in the working age population following a demographic transition destabilizes the political system only when a country is suffering from higher levels of corruption.

We test our hypothesis using panel regressions for more than 150 countries from 2002-2012. To estimate whether the relationship between demographic transitions and political stability varies systematically with the level of corruption, we use the following model: polstab $_{i t}=$ cons $+\beta_{1} \cdot \operatorname{demog}_{i t}+\beta_{2} \cdot \operatorname{cor}_{i t}+\beta_{3} \cdot\left(\operatorname{demog}_{i t} \times \operatorname{cor}_{i t}\right)+\beta_{4} \cdot Z_{i t}+u_{i}+\theta_{t}+\varepsilon_{i t}$, (1)

with country $i$ and time $t$. polstab is the political stability index, demog is the demographic transition, cor is a measure of corruption, demog $\times$ cor is the interaction of the demographic transition and corruption and $Z$ is the control variables. All explanatory variables are lagged one year to reduce possible endogeneity problems (see Mehran and Peristian, 2009; and Bjorvatn, Farzanegan and Schneider, 2012 for a similar approach).

In addition to our main variables of interests (demog, cor and their interaction term), there are other country specific factors that may shape the stability of a political system. Factors such as geographical location, cultural and historical heritage, norms and regional conventions related to the political power, and religion may foster political instability or secure the stability of a system. We control for unobserved time-invariant factors by including country fixed effects $\left(\mu_{\mathrm{i}}\right)$. In addition, we control for the common time shocks that may affect the political stability of all countries in our sample at the same time $\left(\delta_{t}\right)$. Events such as the 9/11 terrorists attack, the Iraq war in 2003 and the Arab Spring are some examples. If such country-specific or time-specific factors are correlated with a demographic transition or corruption, then both pooled cross section and random effects estimations may lead to biased and inconsistent results. $\mathrm{Z}$ covers other control variables, such as natural resource rents (\% of GDP), oil rents (\% of GDP), real GDP per capita, population growth, trade openness, FDI (\% of GDP), and the quality of institutions (voice and accountability, rule of law and government effectiveness). We also control for arbitrary heteroskedasticity and serial correlation by using cluster-robust standard errors at the country level (see Wooldridge, 2002).

\subsection{Dependent and independent variables}


Our dependent variable is political stability and the absence of violence/terrorism, which is based on the World Governance Indicators (WGI) (see Kaufmann, Kraay and Mastruzzi (2010) for more details). This index captures perceptions about the likelihood that the government will be destabilized or overthrown by unconstitutional or violent means, including politically motivated violence and terrorism. We believe that this index captures the political risks of increasing the youth population in a corrupt political economy system. The index ranges approximately from -2.5 to +2.5 . A higher value for the index indicates greater political stability. The WGI indicators, including political stability, are based on the assessments of experts. We address the potential subjective bias in the WGI index of political stability by using fixed effects in which we focus on within country variation in data (see Bezemer and Jong-A-Pin, 2013 for the similar approach). The WGI also measures five other dimensions of good governance, namely control of corruption, regulatory quality, government effectiveness, rule of law and voice and accountability. The WGI indicators are widely used in the literature (see, for example, Kaufmann et al. (2010), Meon and Weill (2005), Easterly (2002), Al-Marhubi (2004), Bjornksov (2006), Aixala and Fabro (2007, 2008), Huynh and Jacho-Chavez (2009), and Langbein and Knack (2010)).

One of our main independent variable is the share of the youth population within the working age population, which is defined as the share of the population aged 17-25 years old in the working age population (15-64 years old). A similar indicator (the ratio of 17-26 year olds to the working age population) is used by Bricker and Foley (2013). Our hypothesis is that a youth population burden may destabilize the political system if corruption is pervasive. To model the conditional effect of youth bulges on political stability, we use a corruption indicator from the WGI database as another main independent variable of interest. In the WGI, corruption captures perceptions of the extent to which public power is exercised for private gain, including both petty and grand forms of corruption, as well as the "capture" of the state by elites and private interests. Thus, it covers both petty and grand corruption in both economic and political zones. A higher score indicates lower corruption. We have reversed the index (by multiplying it by -1) in our analysis; therefore, a higher score indicates greater corruption. To reduce the risk of omitted variable bias, we also control for the logarithm of real GDP per capita, the population growth rate, the share of total natural resource rents in GDP and the share of oil rents in GDP, trade openness (total trade in GDP) and the share of foreign direct investment in GDP and other dimensions of governance, such as voice and accountability, rule of law and government effectiveness (the simple average of these three dimensions) in various specifications. To reduce the reverse feedback from political stability 
on the right hand side (RHS) variables, all independent variables are included with a one-year lag in the models. We also control for country and time unobservable factors, such as geographical location, religion, norms and tradition and year-specific shocks by including country and time fixed effects. We follow a specific to general approach in modelling. We begin by including initially the youth share of the working age population followed by corruption and its interaction with the youth cohort. In subsequent models, we include other control variables one by one until reaching a general model in which we include the full set of control variables. We control for country and time fixed effects in all models. The sample period is 2002-2012. The source of information for demographic variables is the Population Estimates and Projections database of the World Bank. ${ }^{5}$ All other variables, except for governance indicators which are explained earlier, are from the World Bank (2014).

\subsection{Main results}

The fixed effects OLS regressions results are presented in Table 1. In general, as we can see in models 1.1 to 1.11 , the youth bulge, ceteris paribus, is a bonus for stability in political systems. However, this positive outcome, which is also statistically significant in models 1.1$1.3,1.5$, and 1.10 , is not guaranteed. As we observe from the interaction of corruption and youth, the final stability effects of youth bulges within countries and across the world very much depend on the level of corruption. The negative interaction terms show that although the youth population is generally positively associated with stability, this stability effect is only realized in countries with low levels of corruption. In other words, a demographic blessing can be easily turned into a demographic curse for political systems in countries with pervasive corruption.

\footnotetext{
${ }^{5}$ http://data.worldbank.org/data-catalog/population-projection-tables
} 
Table 1. Panel fixed effects regression

\begin{tabular}{|c|c|c|c|c|c|c|c|c|c|c|c|}
\hline & $(1.1)$ & $(1.2)$ & $(1.3)$ & $(1.4)$ & $(1.5)$ & $(1.6)$ & $(1.7)$ & $(1.8)$ & $(1.9)$ & $(1.10)$ & $(1.11)$ \\
\hline & \multicolumn{11}{|c|}{ Dependent variable=Political stability (polstab) } \\
\hline \multirow[t]{2}{*}{ youth $(-1)$} & $3.338 * *$ & $3.348^{* *}$ & $3.434 * *$ & 2.241 & $3.274 * *$ & 1.960 & 2.667 & 1.963 & 2.347 & $3.706^{* *}$ & 1.700 \\
\hline & $(2.06)$ & $(2.21)$ & $(2.22)$ & $(1.65)$ & $(2.11)$ & $(1.45)$ & $(1.35)$ & $(1.33)$ & $(1.63)$ & $(2.43)$ & $(1.25)$ \\
\hline \multirow[t]{2}{*}{ corruption(-1) } & & $-0.278 * * *$ & 0.145 & 0.326 & 0.129 & 0.292 & 0.117 & 0.253 & 0.258 & 0.206 & $0.358^{*}$ \\
\hline & & $(-4.26)$ & $(0.66)$ & $(1.63)$ & $(0.58)$ & $(1.45)$ & $(0.38)$ & $(1.23)$ & $(1.23)$ & $(0.94)$ & $(1.72)$ \\
\hline \multirow[t]{2}{*}{ youth $(-1) \times$ corruption $(-1)$} & & & $-1.570 *$ & $-2.125^{* * *}$ & $-1.503^{*}$ & $-2.054 * * *$ & -1.449 & $-1.845^{* *}$ & $-1.949 * *$ & -1.281 & $-1.702^{* *}$ \\
\hline & & & $(-1.95)$ & $(-2.82)$ & $(-1.87)$ & $(-2.75)$ & $(-1.18)$ & $(-2.40)$ & $(-2.50)$ & $(-1.63)$ & $(-2.26)$ \\
\hline \multirow[t]{2}{*}{$\log _{g} g d p p c(-1)$} & & & & $0.269 * *$ & & & & & & & 0.198 \\
\hline & & & & $(2.02)$ & & & & & & & $(1.40)$ \\
\hline \multirow[t]{2}{*}{$\operatorname{popg}(-1)$} & & & & & 0.0132 & & & & & & 0.009 \\
\hline & & & & & $(0.80)$ & & & & & & $(0.75)$ \\
\hline \multirow[t]{2}{*}{ rent_gdp(-1) } & & & & & & $-0.005^{* *}$ & & & & & $-0.004 *$ \\
\hline & & & & & & $(-2.07)$ & & & & & $(-1.79)$ \\
\hline \multirow[t]{2}{*}{ oil_gdp(-1) } & & & & & & & -0.003 & & & & \\
\hline & & & & & & & $(-0.93)$ & & & & \\
\hline \multirow[t]{2}{*}{ trade_gdp $(-1)$} & & & & & & & & -0.000 & & & -0.000 \\
\hline & & & & & & & & $(-0.08)$ & & & $(-0.01)$ \\
\hline \multirow[t]{2}{*}{$f d i \_g d p(-1)$} & & & & & & & & & -0.0004 & & -0.0004 \\
\hline & & & & & & & & & $(-0.25)$ & & $(-0.28)$ \\
\hline \multirow[t]{2}{*}{ inst(-1) } & & & & & & & & & & $0.447 * * *$ & $0.395^{* * *}$ \\
\hline & & & & & & & & & & (3.94) & (3.27) \\
\hline Observations & 1892 & 1883 & 1883 & 1804 & 1877 & 1801 & 878 & 1778 & 1793 & 1882 & 1712 \\
\hline Within R-sq & 0.01 & 0.05 & 0.06 & 0.06 & 0.06 & 0.07 & 0.06 & 0.05 & 0.05 & 0.08 & 0.09 \\
\hline
\end{tabular}

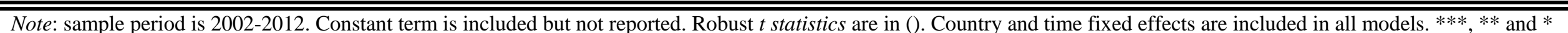
shows statistical significant at $1 \%, 5 \%$ and $10 \%$ levels. 
Model 1.3 shows that greater corruption significantly reduces the positive stability effect of a youth bulge. In models 1.4-1.11, we aim to check the robustness (sign and significance) of the interaction term to the inclusion of other control variables. Can economic development, measured by the lag of income per capita, affect the relevance of corruption in the youthstability nexus? As we see in model 1.4, even including income per capita does not affect the negative sign of the interaction term. Its inclusion increases the magnitude and statistical significance of the interaction term between corruption and youth. Model 1.5 checks for the relevance of the population growth rate as a proxy for an overall increase in the population burden. Again the main findings are not affected.

Total natural resource rents as a share of GDP in the previous year have a negative and statistically significant association with current political stability. This finding is in line with several studies that suggest that higher resource rents increase political instability and intensify conflicts by funding rebel groups, weakening state institutions, and making separatism financially attractive in resource-rich regions (see Collier and Hoeffler (2004), Fearon and Laitin, (2003), and Le Billon (2003)). ${ }^{6}$ Inclusion of this important variable of rents does not wash out the role of interaction between corruption and youth. Still, corruption can significantly modify the stability association of youth bulges.

Model 1.7 looks at a specific form of natural resources, namely oil rents. The effect of oil rents on stability is negative but insignificant. Using oil rents instead of total resource rents also lead to a reduction in observations, from 1801 in the former to 878 in the latter case. Trade openness and foreign direct investment can also shape the stability of political systems. Greater integration in the world economy and more investments can provide new job opportunities, knowledge transfer and human capital formation, which then increases the opportunity costs of instability. However, in our sample, inclusion of trade and FDI indicators does not reduce the importance of the interaction of corruption with youth bulge. Both trade and FDI indicators are statistically insignificant.

Other dimensions of institutions may also affect both corruption and political stability. Thus, we need to control for it to avoid spurious association between our main variables of interest. The voice and accountability of a state, the rule of law and government effectiveness, all in one concept of institutions, have a powerful prediction capacity for current and future changes in the stability of political systems, as is visible in model 1.10. In model 1.11, where we include the entire set of control variables in addition to our three main independent variables,

\footnotetext{
${ }^{6}$ Bjorvatn and Farzanegan (2014) explain that the rent-stability nexus depends on a balance of political power (political factionalism). Also see Farzanegan, Lessman and Markwardt (2013).
} 
our interaction term survives. Corruption matters in the stability-youth bulge association, regardless of the structure of the economy, the size of the country, the degree of globalization and natural resource wealth and the quality of institutions. Finally, we have controlled for education in model 1.11 (not reported). Our proxies are school enrollment at the secondary level (\% gross) and the share of public spending on education in GDP in addition to their interaction with youth population. Would it be a more intellectual society (or youth) that tend to gather and cause instability in the presence of corruption? Or does it stem from societies that are less educated and perhaps poorer as a whole? Our results show that controlling for other variables, education variable and its interaction with youth stability effects are not statistically significant. In addition, we control for interaction of institution variables as defined earlier with youth population in model 1.11. Neither institution nor its interaction term with youth is statistically significant, controlling for other variables. ${ }^{7}$

The overall impact of youth bulges on political stability is positive, but greater corruption in politics and economics moderates this positive effect. In other words, youth populations will be a demographic bomb in corrupt countries where misallocations of resources and opportunities are common. We have also illustrated the marginal impacts of youth bulges on political stability at different levels of corruption, reporting $90 \%$ confidence intervals around estimated marginal effects.

Figure 1 shows the estimation of marginal impacts on the basis of model 1.11 in Table 1 . It shows that when the corruption is under control (i.e., around the minimum of -2.55 , such as in Denmark and Finland), the increasing youth population will act as a bonus for the political system, which is also statistically significant. More corruption will reduce this stability bonus significantly. In extreme situations, where a country's level of corruption is around the maximum range (such as in Equatorial Guinea; Haiti; Korea, Dem. Rep.; Myanmar, and Somalia), the youth bulge acts like a demographic bomb for political stability. The negative zone, however, is not statistically significant. Thus, overall, we have found a youth bulge bonus in our analysis, which can be reduced significantly by increasing corruption.

\footnotetext{
${ }^{7}$ We have also controlled for unemployment, youth total (\% of total labor force ages 15-24) (for male and female separately). We use it in regression analysis for model 1.11 in Table 1 which has also other control variables. Indeed, the one year lag of youth unemployment has a negative effect on stability. Including this variable however does not affect the main interaction term between corruption and youth on stability: it remains negative and significant. Also we tested male and female youth unemployment separately (some countries like Qatar have a very low male youth unemployment while this for female is several times higher). The female youth unemployment is negative and significant while male youth unemployment is not significant (statistically) but negative. We have not reported these additional interactions in table 1 to save the space, but the results are available upon request.
} 
Figure 1. Final stability effect of $1 \%$ increase in the (lag of) youth bulge at different levels of (lag of) corruption

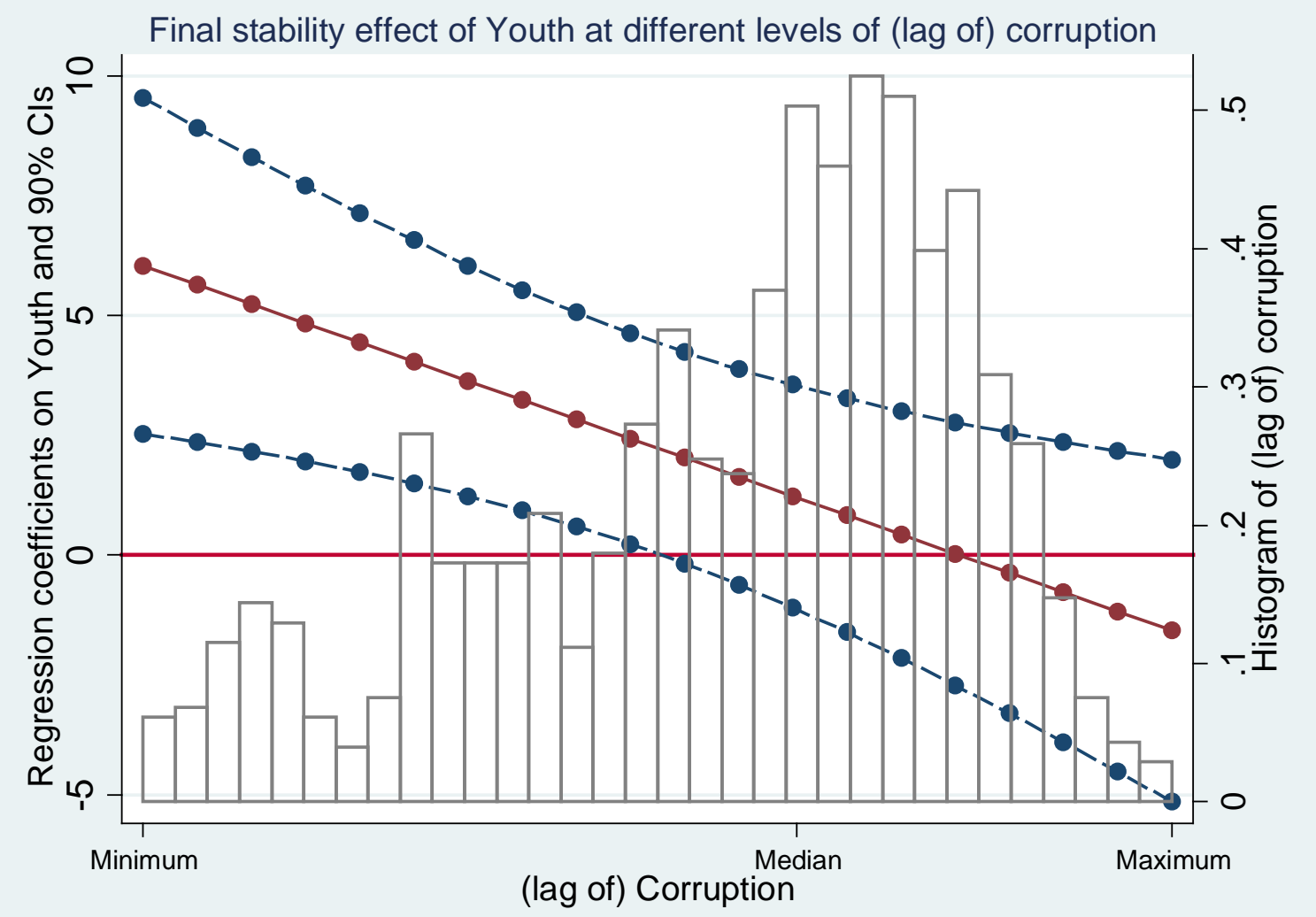

Note: the middle solid line shows the marginal impacts of (lag of) youth on stability at different level of (lag of) corruption. The dashed lines show the error band (at 90\% confidence intervals) around the marginal impact. The calculation is based on the model 1.11 in Table 1 . Note that (lag of) corruption is ranging from minimum -2.55 to maximum 1.92 in our overall sample.

Our dependent variable, political stability, can also be persistent. Conflicts and instabilities in the past are more likely to continue in forthcoming years. Their fluctuations can be highly dependent on their historical development. To control for the possible persistence of stability, we need to control for the lag of the dependent variable in our estimation. Including the lag of stability in the RHS variables in the presence of fixed effects can cause the Nickel Bias. This bias is significant only in the case of short panels. In other word, the bias reduces as the number of periods in the analysis increase (Roodman, 2006). In addition, there is the possibility that our main variables of interest, namely youth bulges, corruption and their interaction terms, at the current time are also affected by political stability in the same year. Instability and terrorism in extreme cases may re-shape demographic variables, though not in the short term, and the quality of control of corruption and the capacities of the state to control corruption. To address all these concerns, we use the (one- and two-steps) system Generalized 
Methods of Moments (GMMs) with heteroskedasticity robust standard errors at the country level. This method of estimation uses lagged values of independent variables (in levels and differences) to instrument the potentially endogenous variables. This method is also efficient when we have the lag of the dependent variable on the right hand side of model (for more information on dynamic system GMMs, see Arellano and Bover (1995) and Blundell and Bond (1998)). Compared with the difference GMM, the system GMM provides more efficient and precise estimates through increasing precision and decreasing the finite sample bias (Baltagi, 2008). In addition, the system GMM keeps the cross-country dimension of the data, which is lost when we use the difference GMM (Castello-Climent, 2008). We instrument the lags of stability, youth, corruption and their interaction term, using 1 to 4 lags of them. Natural resource rents and the quality of institutions are entered into the model using their own lags. The validity of the employed set of instruments is examined through the Hansen statistic. The null hypothesis under the Hansen test is that the used instruments are valid. In our estimations, we cannot reject the null hypothesis (the p-values of the Hansen test are greater than 10\%). We also show test statistics for first and second-order serial correlation in the error process. If the instruments are appropriately uncorrelated with the errors, then we want to reject the presence of second-order serial correlation. As Table 2 shows, our results are also immune to this possibility.

The dynamic panel estimation results in Table 2 show the persistence of stability in political systems. The lag of the dependent variable is positively and significantly correlated with current stability. We control for the lag of natural resource rents in GDP, the lag of the logarithm of GDP per capita and the lag of the quality of institutions (the simple average of voice, rule of law and government effectiveness) in addition to our main variables of interest and fixed effects. There might be other drivers of stability that are not included in the estimation, but their effects are possibly controlled in estimations by including the lag of political stability in the RHS variables (see Sachs and Warner (1997 and 2001) for the similar approach).

The relevant and important question then is whether the interaction of the youth bulge and corruption variables remains in the regression even after controlling for previous political stability. Table 2 shows that interaction term remains negative and statistically significant at conventional levels. We also examined the GMM estimations by using the stability and corruption indicators from the ICRG database. The negative and significant interaction terms between youth population and corruption remains. 
Table 2. Dynamic panel-data estimation

\begin{tabular}{|c|c|c|c|c|}
\hline & $(2.1)$ & $(2.2)$ & $(2.3)$ & $(2.4)$ \\
\hline & $\begin{array}{l}\text { two-step system } \\
\text { GMM }\end{array}$ & $\begin{array}{l}\text { one-step system } \\
\text { GMM }\end{array}$ & $\begin{array}{l}\text { two-step system } \\
\text { GMM }\end{array}$ & $\begin{array}{l}\text { one-step system } \\
\text { GMM }\end{array}$ \\
\hline \multicolumn{5}{|c|}{ Dependent variable: polstab } \\
\hline \multirow{2}{*}{ polstab(-1) } & $0.900 * * *$ & $0.908 * * *$ & $0.903 * * *$ & $0.910 * * *$ \\
\hline & (29.89) & $(34.42)$ & $(30.41)$ & $(34.24)$ \\
\hline \multirow[t]{2}{*}{ youth } & -0.245 & -0.170 & -0.216 & -0.132 \\
\hline & $(-0.49)$ & $(-0.34)$ & $(-0.41)$ & $(-0.27)$ \\
\hline \multirow[t]{2}{*}{ corruption } & 0.0106 & 0.00146 & -0.000346 & -0.00393 \\
\hline & $(0.14)$ & $(0.02)$ & $(-0.00)$ & $(-0.05)$ \\
\hline \multirow[t]{2}{*}{ youth $\times$ corruption } & $-0.563 * *$ & $-0.512 *$ & $-0.527 *$ & $-0.494 *$ \\
\hline & $(-2.05)$ & $(-1.89)$ & $(-1.78)$ & $(-1.78)$ \\
\hline \multirow[t]{2}{*}{ totalrent_gdp(-1) } & -0.00187 & -0.00184 & -0.00200 & -0.00194 \\
\hline & $(-1.41)$ & $(-1.47)$ & $(-1.10)$ & $(-1.18)$ \\
\hline \multirow[t]{2}{*}{ inst(-1) } & -0.0764 & -0.0735 & -0.0851 & -0.0814 \\
\hline & $(-1.11)$ & $(-1.05)$ & $(-0.92)$ & $(-0.99)$ \\
\hline \multirow[t]{2}{*}{$\log \_g d p p c(-1)$} & & & 0.00422 & 0.00326 \\
\hline & & & $(0.16)$ & $(0.14)$ \\
\hline Observations & 1797 & 1797 & 1781 & 1781 \\
\hline No. Instruments & 178 & 178 & 178 & 178 \\
\hline $\begin{array}{l}\text { Hansen J statistic } \\
p \text {-value }\end{array}$ & 0.380 & 0.380 & 0.496 & 0.496 \\
\hline AR(1) $p$-value & 0.00 & 0.00 & 0.00 & 0.00 \\
\hline AR(2) $p$-value & 0.917 & 0.919 & 0.904 & 0.909 \\
\hline
\end{tabular}

Note: Robust t statistics in parentheses. Sample period is 2002-2012. Results generated using the xtabond2 command in Stata, with small sample adjustment and assuming exogeneity of time dummies. Endogenous variables are lags of dependent variable (polstab), youth, corruption, and youth_corruption and are instrumented by 1-4 lags. The AR (2) test and the Hansen $J$ test indicate that there is no further serial correlation, and the overidentifying restrictions are not rejected in all cases.

* Significantly different from zero at $90 \%$ confidence.

** Significantly different from zero at $95 \%$ confidence.

*** Significantly different from zero at $99 \%$ confidence.

\subsection{Robustness checks}

To check the sensitivity of our main findings, we use alternative measurements for corruption and political stability from the International Country Risk Guide (ICRG, 2013) published by the Political Risk Services (PRS) group. One advantage of using the ICRG is its comprehensive coverage of countries over time, which reduces the sample selection bias. The ICRG corruption index is frequently used in the literature (e.g., Biswas et al., 2012; Bjorvatn and Farzanegan, 2013; Alesina and Weder, 2002; Bhattacharyya and Hodler, 2010; Fredriksson and Svensson, 2003; and Knack and Keefer, 1995). The corruption variable ranges from 0 (most corrupt) to 6 (least corrupt). To make the results more interpretable, we 
re-scaled it from 0 (least corrupt) to 1 (most corrupt). This indicator measures corruption in the political system. Political or grand corruption hampers investment and production through the misallocation of economic and human resources on the basis of patronage and nepotism (for the negative effect of corruption on growth, see Knack and Keefer, 1995; Mauro, 1995; Mo, 2001; and Tanzi and Davoodi, 2001, among others). ${ }^{8}$ More specifically, the ICRG corruption indicator aims to cover "actual or potential corruption in the form of excessive patronage, nepotism, job reservations, 'favor-for favors', secret party funding, and suspiciously close ties between politics and business”. This coverage is related to our main research questions, which aim to highlight the role of corruption in destabilizing the political systems in countries experiencing a significant demographic transition. One of the main critiques of the WGI and ICRG indicators is that they measure the perception of corruption (or other dimensions of governance) and perceptions and expert evaluations may not necessarily reflect the reality of governance. We also acknowledge this critique. Corruption as a latent variable is difficult to be measured using objective data. Information such as records of bribery cases in courts or the number of prosecutions related to corruption may not necessarily reflect the size of real corruption but rather the efficiency of the police and judiciary system to address the problem. However, studies show that there is a significant positive correlation between perception-based indicators of corruption and the actual experience of corruption, as measured by International Crime Victim Survey data (Lambsdorff, 2007, see also Biswas et al., 2012 for the similar view).

In addition, we use the internal conflict indicators of the ICRG in our robustness check as a dependent variable. This is an evaluation of the political risk of internal conflict and violence for the governance. It covers three components of risk: civil war and coup treat, terrorism and political violence, and civil disorder. A score of 4 is given to each of these three components will show the lowest risk of conflict. Thus the maximum best grade will be 12, i.e., lack of internal conflict. We have also re-scaled this index from 0 (least internal stability) to 1 (highest internal stability). This index has also been used widely in previous studies (see, for example, Jinjarak, 2009; Farzanegan, Lessmann and Markwardt, 2013; Bjorvatn and Farzanegan, 2013).

Table 3 shows the results using the ICRG indicators of corruption and political stability. We follow the same empirical specifications that we used earlier and presented in Table 1 . The

\footnotetext{
${ }^{8}$ Biswas, Farzanegan and Thum (2012) also show how corruption (which is measured by the ICRG index) can amplify the destructive environmental effects of the shadow economy. Buehn and Farzanegan (2012) and Farzanegan (2009) show how corruption can stimulate smuggling and illicit trade around the world and in the case of Iran, respectively.
} 
results again support our main hypothesis, implying that the positive stability effects of a youth population is significantly reduced at higher levels of corruption within countries, controlling for country and time fixed effects and a set of other control variables.

In other words, to grasp the reasons behind conflicts and instability in countries experiencing a significant demographic transition, especially regarding their young populations, we need to look at corruption perceptions. Political corruption and state captures increase not only income inequality but also inequality in the allocation of opportunities. The international surveys before the Arab Spring political conflicts show that ending corruption was among the top demands of the Arabs. ${ }^{9}$ Ending corruption and nepotism ranked higher than wanting democracy within the Arab societies. Corruption leads to a "de-facto exclusion of the middle classes from opportunities for socioeconomic advancement” (Richards, et al., 2013, p.414). In previous estimations we used the share of population aged 17-25 to population aged 15-64. For robustness check, we estimate the model by using the relative size of population aged 2029 years old to population aged 30-59 as a relative youth cohort size besides the ICRG indicators of corruption and political stability. The results are shown in Table 4. Using a different demographic indicator to measure the relative weight of youth/young cohort of population does not change our main earlier findings. Corruption combined by increasing share of young pool of population is a major risk for the stability of political system worldwide. The corruption matters as significant moderator in stability-youth nexus in almost all models. Finally, the low within country R-squared may initially indicate that our specifications do not explain a major part of internal stability (or conflict). Our main goal, however, is not to explain all within country variations in internal stability in different countries but to test the relevance and importance of moderating role of corruption in stability-youth bulge nexus. ${ }^{10}$

\footnotetext{
${ }^{9}$ For more details on 2005 poll by Zogby International see http://b.3cdn.net/aai/8e7f27fe5092d5bf15_znm6bxbj6.pdf

${ }^{10} \mathrm{R}^{2}$ of the "within" estimation is not correct because the intercept term is suppressed when we estimate the model with fixed effects (see Park 2011). In the -xtreg, fe- calculation, we are washing out the explanatory effects of the intercepts. If we just run the model using linear regression with year and country dummies, those explanatory effects are not removed and we get much higher $\mathrm{R}^{2}$ (see http://www.stata.com/statalist/archive/2003-05/msg00336.html). Finally, the relevance of $\mathrm{R}^{2}$ depends on whether we are testing if corruption moderates the political stability-demographic transition nexus, or whether we are trying to explain what makes countries politically stable. In current analysis, the former part is our goal.
} 
Table 3. Panel fixed effects regression (using ICRG corruption and stability indicators)

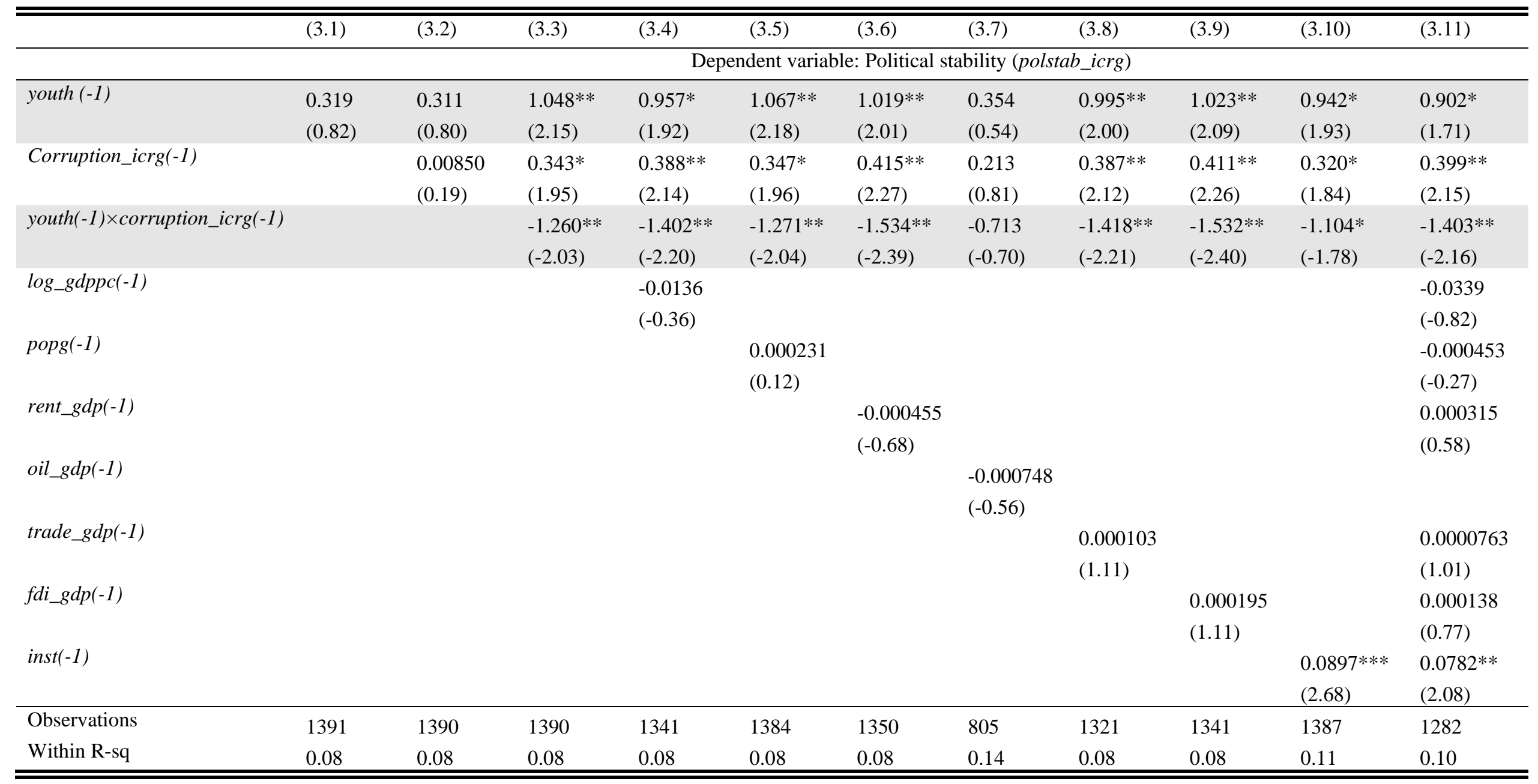

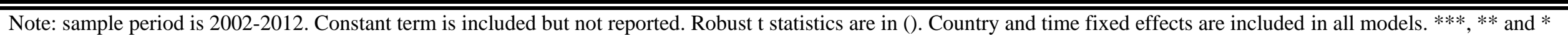
shows statistical significant at $1 \%, 5 \%$ and $10 \%$ levels. 
Table 4. Panel fixed effects regression (using ICRG corruption and stability indicators and population aged 20-29 years old to population aged 30-59)

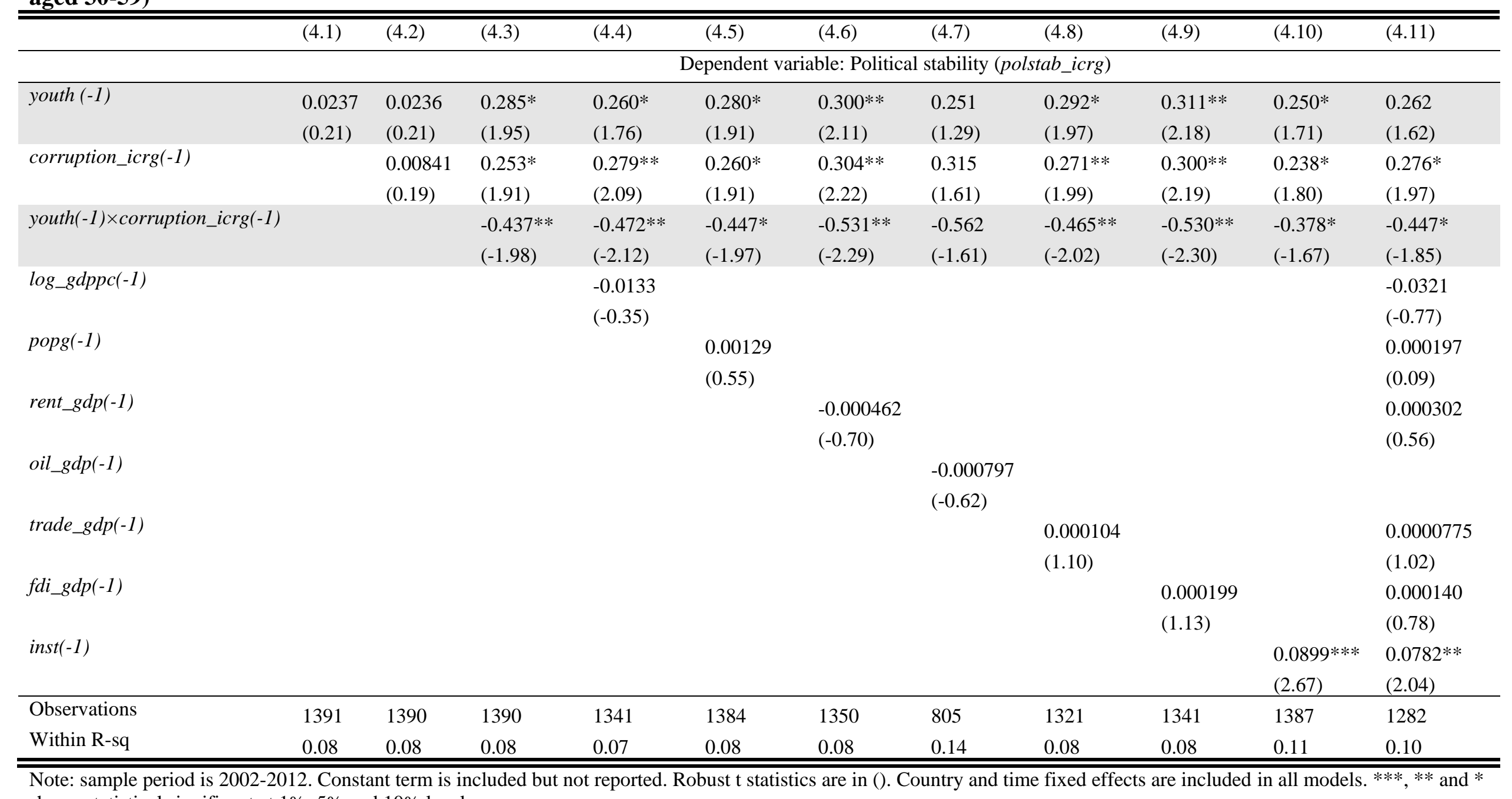

shows statistical significant at $1 \%, 5 \%$ and $10 \%$ levels. 
A final remark on direct positive and often significant estimated coefficient of corruption in Tables 3 and 4: we cannot interpret this positive sign in isolation. This is due to inclusion of interaction term between youth and corruption in models. The final effect of corruption on stability depends on the level of demographic burden of youth. Assuming that share of youth population is zero (which is not the case in our sample); higher corruption has a stabilizer effect. In other words, in the lack of demographic pressure of youth, corrupt political system seems to enjoy a higher political stability. This is in line with previous findings in Fjelde (2009) which shows that "political corruption can be used to accommodate opposition and placate restive groups by offering private privilege in exchange for political loyalty”.

\section{4- Conclusion}

Worldwide we are observing a reduction in fertility rates in developing and transitioning countries, which will consequently lead to larger youth and young cohorts in the population. Such transitions in the demography of a country can provide necessary labor force for production and long-run economic prosperity. However, the window of demographic opportunity, the so-called demographic blessing, can easily turn into a demographic curse (a terminology used by Bjorvatn and Farzanegan, 2013).

In this study, we contribute to the literature by focusing on the political stability effects of a specific type of demographic transition, namely an increase in the size of the youth bulge (17 to 25 years old) within the total working age population or an increase in the population aged 20-29 years compared to the population aged 30-59 years. Our hypothesis is that increasing the youth portion of the working age population can have a destabilizing political effect in corrupt countries. Higher corruption leads to income and opportunity inequality by promoting nepotism and patronage, which then rewards rent-seeking efforts in society. Educated youth populations in corrupt systems have bleak economic prospects. The only options that 'exist' are to immigrate or to transfer to the informal economy and ultimately revolt (see Farzanegan and Badreldin (2014) for the political stability-shadow economy nexus). The so-called Arab Spring in the Middle East and North Africa highlights the importance of demographic transitions in fragile economic systems that are also suffering from high corruption and weak institutions.

Our panel data estimations aim to test the relevance and effect of corruption in stability-youth bulge nexus around the world. Our main variable of interest is the interaction term between corruption and youth bulges. We expect to find a negative interaction term, which implies that demographic transitions, especially those regarding the youth cohort of a population, combined with corruption destabilize the stability of political systems by fostering civil 
disorder. Our analysis of more than 150 countries from 2002 to 2012 supports our hypothesis. The negative interaction term between corruption and youth remains robust when we control for level of income per capita, natural resource rent dependency, trade and foreign direct investment and an average index of institutions (voice, rule of law and government effectiveness), in addition to country and time fixed effects. In the next step, we add a dynamic aspect in our estimations. Political stability may be persistent and slowly changing in nature. In addition, it may have other determinants that we have not included in our model. Including the lag of stability in the set of explanatory variables controls for both concerns. The important question then will be whether our interaction term remains in regressions even after controlling the lag of stability. As our dynamic panel data estimations show, indeed the interaction term survives after controlling the lag of stability in addition to the other variables in model. Using different corruption, stability and youth bulge indicators do not alter our main findings. Thus, we can be more confident about the importance of addressing corruption to hinder costly revolutions in countries that are experiencing significant transitions in their population pyramid. 


\section{References}

Aixala, J., Fabro, G., 2007. A model of growth augmented with institutions. Economic Affairs 27, 71-74.

Aixala, J., Fabro, G., 2008. Does the impact of institutional quality on economic growth depend on initial income level? Economic Affairs 28, 45-49.

Alesina, A., Özler, S., Roubini, N., Swagel, P, 1996. Political instability and economic growth. Journal of Economic Growth 1, 189-211.

Alesina, A., Perotti, R., 1996. Income distribution, political instability, and investment. European Economic Review 40, 1203-28.

Alesina, A., Weder, B., 2002. Do corrupt governments receive less foreign aid? American Economic Review 92, 1126-1137.

Al-Marhubi, F., 2004. The determinants of governance: a cross-country analysis. Contemporary Economic Policy 22, 394-406.

Arellano, M., Bover, O., 1995. Another look at the instrumental variables estimation of error components models. Journal of Econometrics, 68, 29-51.

Baltagi, B. H., 2008. Econometric analysis of panel data (4th Ed.). Chichester: Wiley.

Barakat, B., Urdal, H., 2009. Breaking the waves? Does education mediate the relationship between youth bulges and political violence? Policy Research Working Papers. The World Bank.

Bezemer, D., Jong-A-Pin, R., 2013. Democracy, globalization and ethnic violence. Journal of Comparative Economics 41, 108-125.

Bhattacharyya, S., Hodler, R., 2010. Natural resources, democracy and corruption. European Economic Review 54, 608-621.

Biswas, A., Farzanegan, M.R., Thum, M., 2012. Pollution, shadow economy and corruption: theory and evidence. Ecological Economics 75, 114-125.

Bjornksov, C., 2006. The multiple facets of social capital. European Journal of Political Economy 22, 22-40.

Bjorvatn, K., Farzanegan, M.R., 2014. Resource rents, power, and political stability. CESifo Working Paper Series No. 4727, Munich.

Bjorvatn, K., Farzanegan, M.R., 2013. Demographic transition in resource rich countries: a blessing or a curse? World Development 45, 337-351.

Bjorvatn, K., Farzanegan, M.R., Schneider, F., 2012. Resource curse and power balance: evidence from oil-rich countries. World Development 40, 1308-1316

Blackburn, K., Sarmah, R., 2008. Corruption, development and demography. Economics of Governance 9, 341-62.

Blundell, R., \& Bond, S., 1998. Initial conditions and moment restrictions in dynamic panel data models. Journal of Econometrics, 87, 115-143.

Bricker, N. Q., Foley, M. C., 2013. The effect of youth demographics on violence: the importance of the labor market. International Journal of Conflict and Violence 7, 179-194.

Buehn, A., Farzanegan, M.R., 2012. Smuggling around the World: Evidence from Structural Equation Modeling. Applied Economics 44, 3047-3064. 
Castello-Climent, A., 2008. On the distribution of education and democracy. Journal of Development Economics, 87, 179-190.

Chaaban, J., 2009. Youth and development in the Arab countries: the need for a different approach. Middle Eastern Studies 45, 33-55.

Collier, P., Hoeffler, A., 2004. Greed and grievance in civil war. Oxford Economic Papers 56, 563-595.

Diwan, I., 2013. Understanding revolution in the Middle East: the central role of the middle class. Middle East Development Journal 05, 1350004-1-1350004-30.

Doces, J. A., 2011. Globalization and population: international trade and the demographic transition. International Interactions 37, 127-146.

Dreher, A., Herzfeld, T., 2005. The economic cost of corruption: a survey and new evidence. Public Economics, EconWPA No. 506001, Washington University in St. Louis.

Easterly, W., 2002. The cartel of good intentions: the problem of bureaucracy in foreign aid. Journal of Policy Reform 5, 223-250.

Farzanegan, M.R., 2009. Illegal Trade in the Iranian Economy: Evidence from Structural Equation Model. European Journal of Political Economy 25, 489-507.

Farzanegan, M.R., Badreldin, A., 2014. Shadow economy and political stability: a blessing or a curse? Presented at the 70th Annual Congress of the International Institute of Public Finance, Lugano, Switzerland.

Farzanegan, M.R., Lessman, C., Markwardt, G., 2013. Natural -Resource Rents and Internal Conflicts - Can Decentralization Lift the Curse? CESifo Working Paper Series No. 4180

Fearon, J. D., Laitin, D. D., 2003. Ethnicity, insurgency, and civil war. American Political Science Review 97, 75-90.

Fjelde, H., 2009. Buying Peace? Oil Wealth, Corruption and Civil War, 1985-99. Journal of Peace Research 46, 199-218.

Fredriksson, P.G., Svensson, J., 2003. Political instability, corruption and policy formation: the case of environmental policy. Journal of Public Economics 87, 1383-1405.

Goldstone, J., 2002. Population and security: how demographic change can lead to violent conflict. Journal of International Affairs 56, 3-21.

Gupta, S., Davoodi, H., Alonso-Terme, R., 2002. Does corruption affect income inequality and poverty? Economics of Governance 3, 23-45.

Gupta, S., Davoodi, H., Tiongson, E., 2001. Corruption and the provision of health care and education services. In: Jain, A. K., The Political Economy of Corruption. Routledge, London; New York, pp. 111-141.

Huntington, S.P., 2002. The Clash of Civilizations and the Remarking of World Order. The Free Press, London

Huynh, K.P., Jacho-Chavez, D.T., 2009. Growth and governance: a nonparametric analysis. Journal of Comparative Economics 37, 121-143.

ICRG, 2013. International Country Risk Guide. The PRS Group, New York.

Jinjarak, Y., 2009. Trade variety and political conflict: Some international evidence. Economics Letters 103, 26-28. 
Kaufmann, D., Kraay, A., Mastruzzi, M., 2010. The worldwide governance indicators: methodology and analytical issues. World Bank Policy Research Working Paper No. 5430 .

Knack, S., Keefer, P., 1995. Institutions and economic performance: cross-country tests using alternative institutional measures. Economics and Politics 7, 207-227.

Lambsdorff, J. G., 2007. Causes and consequences of corruption: What do we know from a cross-section of countries? In: Rose-Ackerman, S., International Handbook on the Economics of Corruption. Edward Elgar, Cheltenham, pp. 3-51.

Langbein, L., Knack, S., 2010. The worldwide governance indicators: six, one, or none? Journal of Development Studies 46, 350-370.

Le Billon, P., 2003. Buying peace or fuelling war: the role of corruption in armed conflicts. Journal of International Development 15, 413-426.

Mauro, P., 1995. Corruption and growth. The Quarterly Journal of Economics 110, 681-712.

Mehran, H., Peristiani, S., 2009. Financial visibility and the decision to go private. The Review of Financial Studies 23, 519-547.

Meon, P., Weill, L., 2005. Does better governance foster efficiency? An aggregate frontier analysis. Economics of Governance 6, 75-90.

Mo, P. H., 2001. Corruption and economic growth. Journal of Comparative Economics 29, 66-79.

Moller, H., 1968. Youth as a force in the modern world. Comparative Studies in Society and History 10, 237-260.

Niang, S.R., 2010. Terrorizing ages. The effects of youth density and the relative youth cohort size on the likelihood and pervasiveness of terrorism. Paper presented at the Annual Meeting of the Midwest Political Science Association, April 2010, Chicago

Nordås, R., Davenport, C., 2013. Fight the youth: youth bulges and state repression. American Journal of Political Science 57, 926-940

Nur-Tegin, K., Czap, H. J., 2012. Corruption: democracy, autocracy, and political stability. Economic Analysis and Policy 42, 51-66.

Onuoha, F.C., 2014. Why Do Youth Join Boko Haram? The United States Institute of Peace Special Report No. 348, Washington D.C.

Park, H. M., 2011. Practical Guides to Panel Data Modeling: A Step-by-step Analysis Using Stata. Tutorial Working Paper, International University of Japan. http://www.iuj.ac.jp/faculty/kucc625/method/panel/panel_iuj.pdf

Richards, A., Waterbury, J., Cammett, M., Diwan, I., 2013. A Political Economy of the Middle East: Third Edition, UPDATED 2013 Edition. Westview Press.

Roodman, D., 2006. How to do xtabond2: An introduction to "difference" and "system" GMM in Stata. Center for Global Development Working Paper no. 103.

Sachs, J. D., Warner, A. M., 1997. Sources of slow growth in African economies. Journal of African Economies, 6, 335-376.

Sachs, J. D., Warner, A. M., 2001. The curse of natural resources. European Economic Review 45, 827-838. 
Salti, N., 2013. The economic cost of political instability. LCPS Policy Paper. The Lebanese Center for Policy Studies, Ras Beirut. Available at: http://www.lcpslebanon.org/publications/1368539116-the_economic_cost.pdf

Schomaker, R., Wentzel, D., 2014. Determinants of the emergence (and success) of regime changes: theory and empirical findings (not only) for the Arab spring. Paper presented at the European Public Choice Society Meeting 2014, Cambridge.

Schumacher, I., 2013. Political stability, corruption and trust in politicians. Economic Modelling 31, 359-69.

Tanzi, V., Davoodi, H., 2001. Corruption, growth, and public finances. In: Jain, A.K. (Ed.), Political Economy of Corruption. London: Routledge, pp. 89-110.

Transparency International, 2008. Corruption Perceptions Index 2008. Available at: http://www.transparency.org/research/cpi/cpi_2008\#results.

Treisman, D., 2000. The causes of corruption: a cross-national study. Journal of Public Economics 76, 399-457.

Urdal, H., 2006. A clash of generations? Youth bulges and political violence. International Studies Quarterly 50, 607-629.

Weber, H., 2013. Demography and democracy: the impact of youth cohort size on democratic stability in the world. Democratization 20, 335-357.

Wooldridge, J. M., 2002. Econometric analysis of cross section and panel data. Cambridge, MA: MIT Press.

World Bank, 2014. World Development Indicators. Washington D.C.

Yousef, T., 2003. Youth in the Middle East and North Africa: demography, employment, and conflict. In: Ruble, B. A., Tulchin, J. S., Varat, D. H., Hanley, L. M. (Eds.), Youth Explosion in Developing World Cities. Woodrow Wilson International Center for Scholars, Washington, D.C, pp. 9-24 